\title{
Effect of Corn Particle Size on Site and Extent of Starch Digestion in Lactating Dairy Cows
}

\author{
D. Rémond, ${ }^{1}$ J. I. Cabrera-Estrada, ${ }^{1}$ M. Champion, ${ }^{2}$ B. Chauveau, ${ }^{1}$ \\ R. Coudure, ${ }^{3}$ and C. Poncet ${ }^{1}$ \\ ${ }^{1}$ Unité de Recherches sur les Herbivores \\ Institut National de la Recherche Agronomique \\ 63122 St Genès-Champanelle, France \\ ${ }^{2}$ Limagrain Genetics, 63203 Riom, France \\ ${ }^{3}$ Association Générale des Producteurs de Maïs \\ 64121 Montardon, France
}

\section{ABSTRACT}

Two experiments were conducted to determine the effects of corn particle size (CPS) on site and extent of starch digestion in lactating dairy cows. Animals were fitted with ruminal, duodenal, and ileal cannulas. Dry corn grain accounted for $36 \%$ of dry matter intake. In experiment 1, 6 cows were used in a duplicate $3 \times 3$ Latin square design. Semiflint corn was used. Corn processing methods were grinding, medium rolling, and coarse rolling. The mean particle size of the processed corn was 730,1807 , and $3668 \mu \mathrm{m}$, respectively. Rumen digestibility of starch linearly decreased from $59 \%$ with ground corn to $36 \%$ with coarsely rolled corn. Similarly, small intestine digestibility linearly decreased with increased CPS, and consequently, the amount of starch digested in the small intestine was not affected by corn processing. In experiment 2,4 cows were used in a $2 \times$ 2 crossover design. Dent corn was used. Corn processing methods were grinding and coarse rolling. The mean particle size of the processed corn was 568 and 3458 $\mu \mathrm{m}$, respectively. Rumen digestibility of starch decreased from $70 \%$ with ground corn to $54 \%$ with coarsely rolled corn. Small intestine digestibility of starch was not significantly affected by CPS, and the amount of starch digested in the small intestine tended to be greater for rolled than for ground corn. In both experiments, starch total tract digestibility decreased with increased CPS. In conclusion, CPS is an efficient tool to manipulate rumen degradability of cornstarch. In midlactation cows, the decrease in the amount of starch digested in the rumen between grinding and coarse rolling is partly compensated for by an increase in the amount of starch digested in the small intestine with dent genotype, but with semiflint genotype postruminal

Received July 17, 2003.

Accepted October 14, 2003.

Corresponding author: Didier Rémond; e-mail: dremond@ clermont.inra.fr. digestion is not increased and rumen escape starch is not utilized by the animal.

(Key words: starch, corn, particle size, digestion)

Abbreviation key: CPS = corn particle size, ERD = effective rumen degradability.

\section{INTRODUCTION}

Shifting starch digestion from the rumen to the small intestine has potential benefits. First, starch digestion in the small intestine is energetically more efficient than ruminally fermented starch (Harmon and McLeod, 2001). Second, a decrease in rumen starch digestion may help to limit the incidence of bloat, acidosis, and laminitis (Owens et al., 1998). Mechanistic models were developed to predict the site of starch digestion (rumen, large intestine vs. small intestine) according to grain source and processing, and consequently the nature of the energy substrates (VFA vs. glucose) delivered to the animal (Mills et al., 1999a, 1999b). However, in dairy cows, the lack of in vivo data on starch digestion in the small intestine makes this approach critical. Indeed, although it is well documented that postruminal starch digestion linearly increases over a wide range of starch duodenal flow (Mills et al., 1999b; Oba and Allen, 2003), data on the amount of starch specifically digested in the small intestine are scarce.

The first role of mechanical processing is to break the outer coat of the grain and increase microbial access to starch reserves, and consequently to increase rumen and total tract starch digestion. Now, in situ data suggested a linear inverse relationship between the particle size obtained after processing and ruminal digestibility of corn (Lykos and Varga, 1995). The easiest way to manipulate the site of starch digestion would therefore probably be to vary the mechanical processing. Unfortunately, in vivo data (Knowlton et al., 1998) in lactating dairy cows were less conclusive than 
in situ data. However, as mentioned by the authors, technical difficulties made part of these data uncertain.

In this context, the following studies were conducted to check in vivo the effect of corn particle size (CPS) on the extent of starch digestion in the various segments of the digestive tract (rumen, small intestine, large intestine) of lactating dairy cows. Because the response to grain processing can vary within species of grain, 2 corn cultivars differing by their vitreousness (i.e., massic proportion of horny endosperm in the degermed grain) were tested during 2 successive experiments (experiments 1 and 2). Simultaneously, the effect of corn processing on ruminal starch degradability was studied in situ in dry dairy cows (experiment 3 ).

\section{MATERIALS AND METHODS}

\section{Animals}

Experiment 1. About 2 mo after parturition, 6 multiparous Holstein cows were surgically fitted with permanent cannulas in the rumen (PVC, $106 \mathrm{~mm}$ i.d.), proximal duodenum, and distal ileum (PVC, T-shaped, $19 \mathrm{~mm}$ i.d.). Cows were allowed at least 2-mo recovery from surgery before starting the experiment. Then they were assigned randomly to a duplicate $3 \times 3$ Latin square design. When the experiment started cows were $25 \pm 2$ wk postpartum, and daily milk yield was $21 \pm 1$ $\mathrm{kg} / \mathrm{d}$.

Experiment 2. Four cows from experiment 1 were used during their next lactation in a $2 \times 2$ crossover design. The experiment started $23 \pm 4$ wk postpartum, and daily milk yield was $22 \pm 2 \mathrm{~kg} / \mathrm{d}$.

Experiment 3. Four nonlactating nonpregnant Holstein cows fitted with a ruminal cannula were used for in situ measurement of corn degradability.

\section{Diets and Management}

Experiment 1. Diets were formulated to contain $50 \%$ forage and $35 \%$ of corn grain (Table 1). The texture of the corn grain (Safrane, Limagrain Genetics, France) used in experiment 1 was semiflint. Corn was ground to pass through a $3-\mathrm{mm}$ screen, or it was cracked with a roller mill using 2 gap width settings. Three distinct distributions of particle size were thus obtained. Cows were individually housed in metabolism stalls with free access to water. They were fed twice daily in equal amounts at 0600 and $1800 \mathrm{~h}$. Orts were weighed daily. Cows were milked twice daily in their stalls at 0700 and $1700 \mathrm{~h}$. Each experimental period lasted $28 \mathrm{~d}$ and started with $15 \mathrm{~d}$ of adaptation to the new diet before any measurement.

Experiment 2. Diet composition and cow management were similar to experiment 1 . However, semiflint
Table 1. Ingredients (DM basis) and chemical composition of experimental diets differing in corn processing.

\begin{tabular}{ll}
\hline Item & $\begin{array}{l}\text { Experimental } \\
\text { diet }\end{array}$ \\
\hline Ingredients & $(\%)$ \\
Grass silage ${ }^{1}$ & 34.2 \\
Hay & 16.2 \\
Soybean meal & 10.9 \\
Corn & 36.4 \\
Mineral-vitamin mix ${ }^{2}$ & 1.8 \\
Sodium bicarbonate & 0.6 \\
Chemical composition & \\
DM & 46.2 \\
NE, Mcal/kg of DM & 1.66 \\
OM, \% of DM & 93.4 \\
CP, \% of DM & 15.8 \\
NDF, \% of DM & 37.0 \\
Starch, \% of DM & 26.8 \\
\hline
\end{tabular}

${ }^{1} \mathrm{DM}=24 \% ; \mathrm{OM}=91 \%$ of $\mathrm{DM} ; \mathrm{CP}=14 \%$ of $\mathrm{DM}, \mathrm{MDF}=58 \%$ of DM.

${ }^{2}$ Composition (g/kg): Ca, 240; P, 60; Mg, 50; Na, 20; Zn, 4; Mn,3; $\mathrm{Cu}, 0.8$; retinyl acetate, 1.5 ; cholecalciferol, 0.02 , dl- $\alpha$-tocopherol acetate, 0.5.

corn was replaced by a dent hybrid (Cecilia, Pioneer Hi-Bred, USA) and only 2 mechanical treatments were applied to the grain: corn was ground (3-mm screen) or coarsely rolled.

Experiment 3. Cows received the same diet as in experiment 1 , with medium CPS. They were fed at 0800 and $1700 \mathrm{~h}$.

\section{Measurements}

Experiment 1 and 2. Ruminal juice was collected on $\mathrm{d} 16$ at $0700,1000,1300$, and $1600 \mathrm{~h}$. The $\mathrm{pH}$ was immediately recorded, and the samples were centrifuged at $800 \times g$ for $10 \mathrm{~min}$ at $4^{\circ} \mathrm{C}$ to remove feed particles. Supernatant was subsampled for VFA and ammonia determinations. Samples were stored frozen at $-20^{\circ} \mathrm{C}$. Digesta flow in the intestine was measured by the dual marker technique (Faichney, 1980). Solute and particle markers were Cr-EDTA ( $1 \mathrm{~g}$ of $\mathrm{Cr} / \mathrm{d}$ per cow), and $\mathrm{Yb}$-Acetate (1.5 g of $\mathrm{Yb} / \mathrm{d}$ per cow). They were infused continuously into the rumen, via separate lines, at a rate of $1.2 \mathrm{~L} / \mathrm{d}$ from $\mathrm{d} 16$ to $\mathrm{d} 25$. Total tract digestibility and marker recovery were determined by total collection of urine and faeces over $6 \mathrm{~d}$ (from d 20 to 26). Milk yield and composition were measured for the $6 \mathrm{~d}$ of digestibility studies. For intestinal flow measurements 12 samples were taken from the duodenum and the ileum over $3 \mathrm{~d}$ (from d 22 to $\mathrm{d} 24$ ), so that each 1 $\mathrm{h}$ interval of the 12-h feeding cycle (from 0600 to 1800 h) was represented (4 sampling times at 3 -h interval, per day). Each duodenal $(350 \mathrm{~mL})$ and ileal $(200 \mathrm{~mL})$ digesta sample was immediately subsampled under thorough mixing. One fraction $(100 \mathrm{~mL})$ was kept frozen 
as whole digesta. A second (100 mL) was squeezed dry through nylon gauze $(250 \mu \mathrm{m}$ pore size), and both filtrate and particulate matter were frozen. Fractions from the 12 sampling times were pooled to yield one sample per cow. On d 25, ruminal samples ( $2 \mathrm{~kg}$ ) were collected by suction near the reticulo-omasal orifice at 0600, 1000, and $1400 \mathrm{~h}$. Large particles were withdrawn using a sieve with $4-\mathrm{mm}$ pore size. One liter of filtrate was centrifuged for $10 \mathrm{~min}$ at $800 \times g$ at $4^{\circ} \mathrm{C}$. Precipitate was washed with $\mathrm{NaCl} 0.9 \%$ by manual shaking for 2 min, then centrifuged for $10 \mathrm{~min}$ at $800 \times g$ at $4^{\circ} \mathrm{C}$. Supernatants of the first and the second centrifugation were pooled and centrifuged $20 \mathrm{~min}$ at $27,000 \times \mathrm{g}$ at $4^{\circ} \mathrm{C}$ for precipitation of the bacteria. The pellet of liquid phase bacteria thus obtained was lyophilized. Precipitate of the second centrifugation at $800 \times g$ was suspended in $0.9 \% \mathrm{NaCl}$ and homogenized $3 \times 1$ min at high speed using a Waring Blender. The homogenate was then centrifuged at $800 \times g$ for $10 \mathrm{~min}$ at $4^{\circ} \mathrm{C}$. Solid material was discarded, and the supernatant was centrifuged at $27,000 \times g$ for $20 \mathrm{~min}$ at $4^{\circ} \mathrm{C}$. The pellet of solid-phase bacteria thus obtained was lyophilized. On d 27, a dose of Eu-labeled corn (200 g) was given with the evening meal, and simultaneously a dose of Co-EDTA $(500 \mathrm{~mL})$ was directly added to the rumen via the ruminal cannula. Corn particles were marked with $\mathrm{Eu}$ by soaking in a solution of Eu-chloride $(0.05$ $M, 4 \mathrm{~mL} / \mathrm{g}$ of corn) for $6 \mathrm{~h}$ at $\mathrm{pH} 3$, followed by washing $(6 \times 1 \mathrm{~h}$ in $30 \mathrm{~mL}$ of water/1 $\mathrm{g}$ of corn). Corn particles were dried for $24 \mathrm{~h}$ at $55^{\circ} \mathrm{C}$. Twenty-four hours after dosing, the rumen was totally emptied. Rumen contents were weighed, homogenized, and sampled for DM, Eu, and Co determination.

Experiment 3. For in situ measurements, Dacron bags ( $5 \times 10 \mathrm{~cm}, 50$ to $70 \mu \mathrm{m}$ pore size; Ankom; Fairport; NY) with heat-sealed edges were used. Bags, filled with approximately $3 \mathrm{~g}$ (DM basis) of corn, were incubated in the rumen of each cow for $2,4,8,16,24$, or $48 \mathrm{~h}$. Semiflint (experiment 1) and dent (experiment 2) corn were used as fed to the animals. After removal from the rumen, the bags were washed under cold tap water to remove particles adhering to the outside of the bags and then frozen $\left(-18^{\circ} \mathrm{C}\right)$. After thawing, all the bags were machine-washed $(3 \times 5 \mathrm{~min})$ in cold water and dried $\left(80^{\circ} \mathrm{C}, 48 \mathrm{~h}\right.$, forced-air oven). Each measurement was duplicated.

\section{Laboratory Analyses}

The DM $\left(105^{\circ} \mathrm{C}\right.$ for $\left.24 \mathrm{~h}\right), \mathrm{OM}\left(550^{\circ} \mathrm{C}\right.$ for $\left.6 \mathrm{~h}\right)$, starch (Faisant et al., 1995), and N (Kjeldhal method) content were determined for feeds (fed and refusals), duodenal and ileal whole digesta and filtrate, and feces. Concentrations of $\mathrm{Yb}, \mathrm{Cr}, \mathrm{Eu}$, and $\mathrm{Co}$ in samples were deter- mined using atomic absorption spectrophotometry. The NH3 $N$ concentration in ruminal fluid and intestinal digesta was determined by automated procedures using the hypochlorite method (Weatherburn, 1967). Analysis of VFA in the ruminal fluid was completed using a gas chromatograph (Jouany, 1982). Puric and pyrimidic bases were determined in duodenal and bacterial samples by HPLC after perchloric acid hydrolysis (Lassalas et al., 1993). Milk fat, protein, and lactose contents were determined by infrared analysis (Milkoscan, Foss Electric, Hillerød, Denmark).

Corn particle size was measured by dry sieving. Mean particle size was calculated by fitting the data to a log normal distribution (Waldo et al., 1971).

\section{Calculation and Statistical Analysis}

Nutrient flows to the duodenum and ileum were calculated using the reconstitution procedure of Faichney (1980). To calculate the proportion of duodenal nonammonia $\mathrm{N}$ of microbial origin, the sum of bases was taken as the reference for nucleic acid content, and the representative sample of bacteria flowing to the duodenum was estimated to be $70 \%$ solid-phase bacteria and $30 \%$ liquid phase bacteria. Passage rate of rumen liquid and corn particles were calculated assuming an exponential decrease against time in $\mathrm{Co}$ and Eu concentrations within the ruminal content, over a 24 -h period (from marker dosing to rumen emptying, assuming a similar amount of rumen content at both times).

The starch degradation kinetics obtained for each corn sample and each cow were fitted to an exponential model using the nonlinear regression procedure of SAS (1988): Disappearance $(\mathrm{t})=\mathrm{a}+\mathrm{b}\left(1-\mathrm{e}^{-\mathrm{ct}}\right)$, where $\mathrm{a}=$ soluble fraction (\%), $\mathrm{b}=$ slowly degradable fraction $(\%)$, $\mathrm{c}=$ fractional rate constant at which $\mathrm{b}$ is degraded, and $\mathrm{t}=$ time of incubation. Effective ruminal degradability (ERD) of starch was calculated with the equation of Ørskov and McDonald (1979) using the fractional passage rate $\left(\mathrm{k}_{\mathrm{p}}\right)$ observed in the present study.

Data were analyzed by ANOVA using the GLM procedure of SAS (1988), using a model with cow, period, and treatment as independent variables. In experiments 1 and 2, when treatment effect was significant $(P<0.05)$, linear and quadratic effects of CPS were determined after the coefficients were adjusted for unequal spacing of mean particle size.

\section{RESULTS}

\section{Processed Grain Characteristics}

Starch content of corn grain was 73.6 and $73.4 \%$ of DM for semiflint and dent genotype, respectively. Mean particle size of corn in experiment 1 was 730,1807 , 
Table 2. Influence of processing on in situ ruminal starch degradability (experiment 3).

\begin{tabular}{|c|c|c|c|c|c|c|}
\hline \multicolumn{2}{|l|}{$\begin{array}{l}\text { Mean particle } \\
\text { size, mm }\end{array}$} & \multirow[t]{2}{*}{$a^{1}, \%$} & \multirow[t]{2}{*}{$\mathrm{b}^{2}, \%$} & \multirow{2}{*}{$\frac{\mathrm{c}^{3}, \% \cdot \mathrm{h}^{-1}}{\text { Semiflint cor }}$} & \multirow[t]{2}{*}{$\mathrm{k}_{\mathrm{p}}^{4}$} & \multirow[t]{2}{*}{$\mathrm{ERD}_{\mathrm{kp}}{ }^{5}$} \\
\hline & & & & & & \\
\hline 0.7 & & $18.4^{\mathrm{a}}$ & $81.6^{\mathrm{a}}$ & $5.6^{\mathrm{a}}$ & 4.99 & $61.6^{\mathrm{a}}$ \\
\hline 1.8 & & $8.7^{\mathrm{b}}$ & $91.3^{b}$ & $5.7^{\mathrm{a}}$ & 5.16 & $56.6^{\mathrm{b}}$ \\
\hline \multirow[t]{4}{*}{3.7} & & $1.9^{\mathrm{c}}$ & $98.1^{\mathrm{c}}$ & $4.0^{\mathrm{b}}$ & 4.27 & $49.5^{\mathrm{c}}$ \\
\hline & SE & 1.5 & 1.5 & 0.1 & 0.16 & 10.3 \\
\hline & & 0.004 & 0.004 & 0.002 & 0.105 & 0.001 \\
\hline & Contrasts $^{6}$ & $\mathrm{~L}$ & $\mathrm{~L}$ & $\mathrm{~L}, \mathrm{Q}$ & & $\mathrm{L}$ \\
\hline 0.6 & & 24.9 & 75.1 & 5.4 & 4.67 & 65.0 \\
\hline \multirow[t]{3}{*}{3.5} & & 0.4 & 99.6 & 4.2 & 4.15 & 50.3 \\
\hline & SE & 0.5 & 0.5 & 0.1 & 0.42 & 0.3 \\
\hline & $P$ & 0.001 & 0.001 & 0.003 & 0.475 & 0.001 \\
\hline
\end{tabular}

${ }^{\mathrm{a}, \mathrm{b}, \mathrm{c}}$ Means within a column not sharing a common superscript differ $(P<0.05)$.

${ }^{1} \mathrm{a}=$ Rapidly degradable fraction.

${ }^{2} \mathrm{~b}=$ Slowly degradable fraction.

${ }^{3} \mathrm{c}=$ Fractional rate constant at which $\mathrm{b}$ is degraded.

${ }^{4} k_{p}=$ Corn particle outflow rate $(n=6$ in experiment 1 and $n=4$ in experiment 2$)$.

${ }^{5} \mathrm{ERD}=$ Effective rumen degradability $(\%)$ calculated for the measured passage rate of corn particles $\left(\mathrm{k}_{\mathrm{p}}\right)$.

${ }^{6}$ Linear $(\mathrm{L})$ or quadratic $(\mathrm{Q})$ effects of mean particle size, $P<0.05$.

and $3668 \mu \mathrm{m}$, for grinding, medium rolling, and coarse rolling, respectively. In experiment 2 it was 568 and $3458 \mu \mathrm{m}$ for grinding and coarse rolling, respectively. With both genotypes, coarse rolling left about $4 \%$ of unbroken grains. Corn passage rate was not significantly affected by processing for either hybrid (Table 2 ). In situ ruminal degradation of cornstarch showed that increasing the intensity of corn processing (decreasing particle size) increases the soluble fraction (a), and it decreases the potentially degradable fraction (b). The fractional rate of starch degradation (c) increased with corn processing. Data obtained with semiflint corn suggested that this increase was quadratically related to mean particle size (Table 2). For both corn genotypes, starch ERD increased with increased corn processing. Data obtained with semiflint corn suggested a linear relationship between ERD and CPS.

\section{Digestion}

Experiment 1. Dry matter intake was similar for all $\operatorname{diets}(15.9 \pm 0.2 \mathrm{~kg} / \mathrm{d})$. Rumen $\mathrm{pH}$ and VFA concentrations were not significantly affected by grain processing (Table 3). However, rumen ammonia linearly increased with CPS. Apparent digestibility of OM linearly decreased $(P<0.05)$ with CPS in the stomachs, and it tended to decrease $(P<0.10)$ in the small intestine (Table 4). As a result, total tract apparent digestibility of OM linearly decreased when corn was fed as larger particles. Intake of starch was similar for cows fed the various form of corn (Table 5). Duodenal flow of starch linearly increased with CPS. Rumen digestibility of starch linearly decreased from 58.6\% with ground corn to $35.5 \%$ with coarsely rolled corn. Starch digestibility in the small intestine linearly decreased with increasing CPS. Although there was an increase in starch entry into the small intestine, the amount of starch digested in the small intestine was not affected by corn processing. Starch total tract digestibility linearly decreased with increasing CPS. A linear decrease in total tract $\mathrm{N}$ digestibility was observed from ground to coarsely rolled grain. The other parameters of $\mathrm{N}$ digestion were not affected (Table 6). Milk production and protein content tend to decrease $(P<0.10)$ with increased CPS of corn (Table 7).

Experiment 2. Corn processing did not affect ruminal fermentation traits (Table 8). Parameters of OM digestion are presented in Table 9. The amount of starch digested in the rumen was greater $(P<0.05)$ for ground than for rolled corn (Table 10). Small intestine digestibility of starch was not significantly affected by corn processing, and the amount of starch digested in the small intestine tended to be greater for rolled than for ground corn $(P<0.10)$. Total tract digestibility of starch decreased $(P<0.01)$ between ground and rolled grain. Corn processing (Table 11) did not affect parameters of $\mathrm{N}$ digestion. Milk production was similar among the treatments (Table 12). However, lactose production was lower for rolled than for ground corn $(P<0.01)$.

\section{DISCUSSION}

A wide range of in situ rumen starch degradability (from 0.41 to 0.78 ) has been reported according to corn 
Table 3. Effect of semiflint corn processing on the daily mean of ruminal $\mathrm{pH}$, VFA and ammonia concentration, and liquid outflow rate (experiment $1 ; \mathrm{n}=6$ ).

\begin{tabular}{|c|c|c|c|c|c|c|}
\hline \multirow[b]{2}{*}{ Item } & \multicolumn{3}{|c|}{ Mean particle size, mm } & \multirow[b]{2}{*}{$\mathrm{SE}$} & \multicolumn{2}{|c|}{ Statistics } \\
\hline & 0.7 & 1.8 & 3.7 & & $P$ & Effect $^{1}$ \\
\hline $\mathrm{pH}$ & 6.46 & 6.45 & 6.47 & 0.03 & 0.909 & \\
\hline VFA, $\mathrm{m} M$ & 91.5 & 94.5 & 95.6 & 2.25 & 0.444 & \\
\hline Acetate, $\%$ & 64.1 & 64.3 & 64.6 & 0.33 & 0.542 & \\
\hline Propionate, \% & 19.8 & 21.2 & 19.9 & 0.38 & 0.785 & \\
\hline Butyrate, \% & 11.7 & 11.4 & 11.3 & 0.31 & 0.661 & \\
\hline Ammonia, $\mathrm{m} M$ & $5.2^{\mathrm{b}}$ & $5.6^{\mathrm{b}}$ & $6.7^{\mathrm{a}}$ & 0.30 & 0.019 & $\mathrm{~L}$ \\
\hline Liquid passage rate, $\% / \mathrm{h}$ & 11.8 & 12.0 & 11.6 & 0.17 & 0.278 & \\
\hline
\end{tabular}

a,b,c Means within a row not sharing a common superscript differ $(P<0.05)$.

${ }^{1}$ Linear $(\mathrm{L})$ or quadratic $(\mathrm{Q})$ effect of mean particle size, $P<0.05$.

Table 4. Organic matter intake, flow, and apparent digestibility in lactating dairy cows fed diets differing in semiflint corn processing (experiment $1 ; \mathrm{n}=6$ ).

\begin{tabular}{|c|c|c|c|c|c|c|}
\hline \multirow[b]{2}{*}{ Item } & \multicolumn{3}{|c|}{ Mean particle size, mm } & \multirow[b]{2}{*}{$\mathrm{SE}$} & \multicolumn{2}{|c|}{ Statistics } \\
\hline & 0.7 & 1.8 & 3.7 & & $P$ & Effect $^{1}$ \\
\hline Intake, $\mathrm{kg} / \mathrm{d}$ & 15.0 & 14.8 & 14.9 & 0.25 & 0.934 & \\
\hline \multicolumn{7}{|l|}{ Flow, kg/d } \\
\hline Duodenum & 7.8 & 8.4 & 8.7 & 0.24 & 0.213 & \\
\hline Terminal ileum & $3.6^{\mathrm{b}}$ & $4.0^{\mathrm{b}}$ & $4.8^{\mathrm{a}}$ & 0.16 & 0.002 & $\mathrm{~L}$ \\
\hline \multicolumn{7}{|c|}{ Apparent digestibility \% } \\
\hline Reticulorumen & $47.9^{\mathrm{a}}$ & $43.2^{\mathrm{b}}$ & $41.4^{\mathrm{c}}$ & 1.39 & 0.028 & $\mathrm{~L}$ \\
\hline Small intestine & 54.2 & 51.6 & 44.2 & 2.59 & 0.062 & \\
\hline Whole tract & $73.7^{\mathrm{a}}$ & $71.9^{\mathrm{b}}$ & $68.3^{\mathrm{c}}$ & 0.42 & 0.001 & $\mathrm{~L}$ \\
\hline
\end{tabular}

a,b,c Means within a row not sharing a common superscript differ $(P<0.05)$.

${ }^{1}$ Linear $(\mathrm{L})$ or quadratic $(\mathrm{Q})$ effect of mean particle size, $P<0.05$.

Table 5. Starch intake, flow, and apparent digestibility in lactating dairy cows fed diets differing in corn processing (experiment $1 ; \mathrm{n}=6$ ).

\begin{tabular}{|c|c|c|c|c|c|c|}
\hline \multirow[b]{2}{*}{ Item } & \multicolumn{3}{|c|}{ Mean particle size, mm } & \multirow[b]{2}{*}{ SE } & \multicolumn{2}{|c|}{ Statistics } \\
\hline & 0.7 & 1.8 & 3.7 & & $P$ & Effect $^{1}$ \\
\hline Intake, $\mathrm{kg} / \mathrm{d}$ & 4.33 & 4.33 & 4.27 & 0.05 & 0.654 & \\
\hline \multicolumn{7}{|l|}{ Flow, kg/d } \\
\hline Duodenum & $1.80^{\mathrm{b}}$ & $2.17^{\mathrm{b}}$ & $2.75^{\mathrm{a}}$ & 0.12 & 0.002 & $\mathrm{~L}$ \\
\hline Terminal ileum & $0.54^{\mathrm{c}}$ & $0.81^{\mathrm{b}}$ & $1.44^{\mathrm{a}}$ & 0.05 & 0.001 & $\mathrm{~L}$ \\
\hline \multicolumn{7}{|l|}{ Apparently digested in rumen } \\
\hline $\mathrm{kg} / \mathrm{d}$ & $2.53^{\mathrm{a}}$ & $2.16^{\mathrm{a}}$ & $1.52^{\mathrm{b}}$ & 0.12 & 0.001 & $\mathrm{~L}$ \\
\hline$\%$ of intake & $58.6^{\mathrm{a}}$ & $49.8^{\mathrm{a}}$ & $35.5^{\mathrm{b}}$ & 2.8 & 0.001 & $\mathrm{~L}$ \\
\hline \multicolumn{7}{|l|}{ Apparently digested in small intestine } \\
\hline $\mathrm{kg} / \mathrm{d}$ & 1.26 & 1.36 & 1.30 & 0.13 & 0.839 & \\
\hline$\%$ of duodenal passage & $67.5^{\mathrm{a}}$ & $61.1^{\mathrm{a}}$ & $47.0^{\mathrm{b}}$ & 3.3 & 0.006 & $\mathrm{~L}$ \\
\hline$\%$ of intake & 28.9 & 31.5 & 30.6 & 2.8 & 0.803 & \\
\hline \multicolumn{7}{|l|}{ Apparently digested in large intestine } \\
\hline $\mathrm{kg} / \mathrm{d}$ & 0.20 & 0.17 & 0.14 & 0.07 & 0.798 & \\
\hline$\%$ of ileal passage & 30.5 & 18.8 & 9.3 & 6.3 & 0.115 & \\
\hline$\%$ of intake & 4.0 & 4.7 & 3.4 & 1.6 & 0.841 & \\
\hline Apparently digested in the total tract, $\%$ & $91.4^{\mathrm{a}}$ & $86.0^{\mathrm{b}}$ & $69.5^{\mathrm{c}}$ & 0.8 & 0.001 & $\mathrm{~L}$ \\
\hline
\end{tabular}

a,b,c Means within a row not sharing a common superscript differ $(P<0.05)$.

${ }^{1}$ Linear $(\mathrm{L})$ or quadratic $(\mathrm{Q})$ effect of mean particle size, $P<0.05$. 
Table 6. Nitrogen intake, flow, and apparent digestibility in lactating dairy cows fed diets differing in corn processing (experiment $1 ; \mathrm{n}=6$ ).

\begin{tabular}{|c|c|c|c|c|c|c|}
\hline \multirow[b]{2}{*}{ Item } & \multicolumn{3}{|c|}{ Mean particle size, $\mathrm{mm}$} & \multirow[b]{2}{*}{$\mathrm{SE}$} & \multicolumn{2}{|c|}{ Statistics } \\
\hline & 0.7 & 1.8 & 3.7 & & $P$ & Effect $^{1}$ \\
\hline $\mathrm{N}$ intake, $\mathrm{g} / \mathrm{d}$ & 401 & 398 & 397 & 6.5 & 0.911 & \\
\hline \multicolumn{7}{|l|}{ Flow to the duodenum } \\
\hline Total N, g/d & 375 & 391 & 376 & 9.0 & 0.417 & \\
\hline $\mathrm{NAN}^{2}, \mathrm{~g} / \mathrm{d}$ & 362 & 377 & 361 & 11.6 & 0.403 & \\
\hline Microbial NAN & 226 & 213 & 201 & 10.6 & 0.307 & \\
\hline Nonmicrobial NAN & 136 & 165 & 160 & 7.6 & 0.331 & \\
\hline \multicolumn{7}{|l|}{ Microbial protein synthesis } \\
\hline $\mathrm{g}$ of $\mathrm{CP} / \mathrm{kg} \mathrm{OMADR}^{3}$ & 198 & 208 & 215 & 10.1 & 0.565 & \\
\hline $\mathrm{g}$ of $\mathrm{CP} / \mathrm{kg} \mathrm{OMTDR}{ }^{4}$ & 145 & 150 & 152 & 5.2 & 0.658 & \\
\hline NAN flow to the ileum, g/d & 129 & 130 & 131 & 4.5 & 0.940 & \\
\hline \multicolumn{7}{|l|}{ Apparently digested in small intestine } \\
\hline $\mathrm{g} / \mathrm{d}$ & 241 & 254 & 236 & 9.3 & 0.406 & \\
\hline$\%$ of duodenal passage & 66.6 & 68.4 & 65.5 & 1.73 & 0.528 & \\
\hline$\%$ of intake & 60.1 & 63.9 & 59.5 & 2.47 & 0.421 & \\
\hline $\begin{array}{l}\mathrm{N} \text { apparently digested } \\
\text { in the total tract, } \%\end{array}$ & $66.1^{\mathrm{a}}$ & $65.6^{\mathrm{a}}$ & $63.9^{\mathrm{b}}$ & 0.50 & 0.033 & $\mathrm{~L}$ \\
\hline
\end{tabular}

a,b,c Means within a row not sharing a common superscript differ $(P<0.05)$.

${ }^{1}$ Linear (L) or quadratic (Q) effect of mean particle size, $\mathrm{P}<0.05$.

${ }^{2} \mathrm{NAN}=$ nonammonia $\mathrm{N}$.

${ }^{3} \mathrm{OMADR}=$ organic matter apparently digested in the rumen.

${ }^{4}$ OMTDR $=$ organic matter truly digested in the rumen.

Table 7. Intake, milk production, and milk composition of cows fed diets differing in corn processing (experiment $1 ; \mathrm{n}=6$ ).

\begin{tabular}{|c|c|c|c|c|c|}
\hline \multirow[b]{2}{*}{ Item } & \multicolumn{3}{|c|}{ Mean corn particle size, $\mathrm{mm}$} & \multicolumn{2}{|c|}{ Statistics } \\
\hline & 0.7 & 1.8 & 3.7 & $\mathrm{SE}$ & $P$ \\
\hline DMI, kg/d & 16.0 & 15.9 & 15.9 & 0.27 & 0.939 \\
\hline Milk production, $\mathrm{kg} / \mathrm{d}$ & 19.8 & 18.3 & 18.2 & 0.05 & 0.069 \\
\hline \multicolumn{6}{|l|}{ Milk fat } \\
\hline$\%$ & 4.13 & 4.15 & 4.14 & 0.52 & 0.958 \\
\hline $\mathrm{g} / \mathrm{d}$ & 810 & 754 & 750 & 23 & 0.121 \\
\hline \multicolumn{6}{|l|}{ Milk protein } \\
\hline$\%$ & 3.07 & 3.10 & 2.95 & 0.04 & 0.085 \\
\hline $\mathrm{g} / \mathrm{d}$ & 601 & 558 & 534 & 20 & 0.173 \\
\hline \multicolumn{6}{|l|}{ Lactose } \\
\hline$\%$ & 4.91 & 4.82 & 4.88 & 0.05 & 0.442 \\
\hline $\mathrm{g} / \mathrm{d}$ & 967 & 890 & 883 & 29 & 0.134 \\
\hline
\end{tabular}

Table 8. Effect of corn processing on the daily mean of ruminal pH, VFA and ammonia concentration, and liquid outflow rate (experiment $2 ; \mathrm{n}=4$ ).

\begin{tabular}{|c|c|c|c|c|}
\hline \multirow[b]{2}{*}{ Item } & \multicolumn{2}{|c|}{ Dry corn } & \multicolumn{2}{|c|}{ Statistics } \\
\hline & Ground & Rolled & $\mathrm{SE}$ & $P$ \\
\hline $\mathrm{pH}$ & 6.57 & 6.65 & 0.06 & 0.466 \\
\hline VFA, $\mathrm{m} M$ & 95.6 & 97.8 & 2.71 & 0.617 \\
\hline Acetate, $\%$ & 65.4 & 66.9 & 0.43 & 0.131 \\
\hline Propionate, $\%$ & 19.1 & 19.2 & 0.40 & 0.877 \\
\hline Butyrate, \% & 11.5 & 10.2 & 0.93 & 0.436 \\
\hline Ammonia, $\mathrm{m} M$ & 6.1 & 7.1 & 0.80 & 0.350 \\
\hline Liquid passage rate, $\% / \mathrm{h}$ & 11.1 & 9.7 & 0.42 & 0.141 \\
\hline
\end{tabular}


Table 9. Organic matter intake, flow, and apparent digestibility in lactating dairy cows fed diets differing in corn processing (experiment $2 ; \mathrm{n}=4$ ).

\begin{tabular}{|c|c|c|c|c|}
\hline \multirow[b]{2}{*}{ Item } & \multicolumn{2}{|c|}{ Dry corn } & \multicolumn{2}{|c|}{ Statistics } \\
\hline & Ground & Rolled & $\mathrm{SE}$ & $P$ \\
\hline Intake, $\mathrm{kg} / \mathrm{d}$ & 16.36 & 16.49 & 0.07 & 0.342 \\
\hline \multicolumn{5}{|l|}{ Flow, kg/d } \\
\hline Duodenum & 6.84 & 6.51 & 0.17 & 0.302 \\
\hline Terminal ileum & 3.59 & 4.20 & 0.05 & 0.015 \\
\hline \multicolumn{5}{|c|}{ Apparent digestibility \% } \\
\hline Reticulorumen & 58.2 & 60.5 & 0.9 & 0.208 \\
\hline Small intestine & 47.4 & 35.6 & 0.7 & 0.007 \\
\hline Whole tract & 76.7 & 73.0 & 0.9 & 0.028 \\
\hline
\end{tabular}

Table 10. Starch intake, flow, and apparent digestibility in lactating dairy cows fed diets differing in corn processing (experiment $2 ; \mathrm{n}=4$ ).

\begin{tabular}{|c|c|c|c|c|}
\hline \multirow[b]{2}{*}{ Item } & \multicolumn{2}{|c|}{ Dry corn } & \multicolumn{2}{|c|}{ Statistics } \\
\hline & Ground & Rolled & $\mathrm{SE}$ & $P$ \\
\hline Intake, kg/d & 4.73 & 4.66 & 0.04 & 0.286 \\
\hline \multicolumn{5}{|l|}{ Flow, kg/d } \\
\hline Duodenum & 1.43 & 2.17 & 0.06 & 0.014 \\
\hline Terminal ileum & 0.32 & 0.68 & 0.03 & 0.014 \\
\hline \multicolumn{5}{|c|}{ Apparently digested in rumen } \\
\hline $\mathrm{kg} / \mathrm{d}$ & 3.30 & 2.49 & 0.09 & 0.026 \\
\hline$\%$ of intake & 69.8 & 53.5 & 1.5 & 0.018 \\
\hline \multicolumn{5}{|c|}{ Apparently digested in small intestine } \\
\hline $\mathrm{kg} / \mathrm{d}$ & 1.11 & 1.48 & 0.08 & 0.082 \\
\hline$\%$ of duodenal passage & 77.8 & 68.3 & 3.0 & 0.152 \\
\hline$\%$ of intake & 23.4 & 31.9 & 2.0 & 0.092 \\
\hline \multicolumn{5}{|c|}{ Apparently digested in large intestine } \\
\hline $\mathrm{kg} / \mathrm{d}$ & 0.19 & 0.18 & 0.03 & 0.705 \\
\hline$\%$ of ileal passage & 59.2 & 25.3 & 2.5 & 0.011 \\
\hline$\%$ of intake & 4.1 & 3.8 & 0.6 & 0.738 \\
\hline $\begin{array}{l}\text { Apparently digested in } \mathrm{t} \\
\text { total tract, } \%\end{array}$ & 97.3 & 89.2 & 0.2 & 0.001 \\
\hline
\end{tabular}

Table 11. Nitrogen intake, flow, and apparent digestibility in lactating dairy cows fed diets differing in corn processing (experiment $2 ; \mathrm{n}=4$ ).

\begin{tabular}{|c|c|c|c|c|}
\hline \multirow[b]{2}{*}{ Item } & \multicolumn{2}{|c|}{ Dry corn } & \multicolumn{2}{|c|}{ Statistics } \\
\hline & Ground & Rolled & $\mathrm{SE}$ & $P$ \\
\hline N Intake, g/d & 434 & 438 & 2.2 & 0.277 \\
\hline \multicolumn{5}{|l|}{ Flow to the duodenum } \\
\hline Total N, g/d & 337 & 341 & 7.6 & 0.717 \\
\hline $\mathrm{NAN}^{1}, \mathrm{~g} / \mathrm{d}$ & 324 & 327 & 7.1 & 0.793 \\
\hline Microbial NAN & 241 & 227 & 13.2 & 0.529 \\
\hline Nonmicrobial NAN & 83 & 100 & 17.1 & 0.555 \\
\hline \multicolumn{5}{|l|}{ Microbial protein synthesis } \\
\hline $\mathrm{g}$ of $\mathrm{CP} / \mathrm{kg} \mathrm{OMADR} \mathrm{OM}^{2}$ & 159 & 144 & 8.3 & 0.325 \\
\hline g of $\mathrm{CP} / \mathrm{kg} \mathrm{OMTDR}{ }^{3}$ & 123 & 113 & 4.8 & 0.280 \\
\hline NAN flow to the ileum, g/d & 126 & 134 & 4.3 & 0.298 \\
\hline \multicolumn{5}{|l|}{ Apparently digested in the small intestine } \\
\hline $\mathrm{g} / \mathrm{d}$ & 199 & 193 & 10.4 & 0.729 \\
\hline$\%$ of duodenal passage & 61.2 & 59.1 & 2.0 & 0.528 \\
\hline$\%$ of $\mathrm{N}$ intake & 46.1 & 44.1 & 2.2 & 0.593 \\
\hline \multicolumn{5}{|l|}{$\mathrm{N}$ apparently digested in the } \\
\hline total tract, $\%$ & 65.8 & 64.9 & 0.6 & 0.417 \\
\hline
\end{tabular}

${ }^{1} \mathrm{NAN}=$ nonammonia $\mathrm{N}$.

${ }^{2}$ OMADR = Organic matter apparently digested in the rumen.

${ }^{3} \mathrm{OMTDR}=$ Organic matter truly digested in the rumen. 
Table 12. Intake, milk production, and milk composition of cows fed diets differing in corn processing (experiment $2 ; \mathrm{n}=4$ ).

\begin{tabular}{lccccc}
\hline & \multicolumn{2}{c}{ Dry corn } & & \multicolumn{2}{c}{ Statistics } \\
\cline { 2 - 3 } \cline { 5 - 6 } Item & Ground & Rolled & & SE & $P$ \\
\hline DMI, kg/d & 18.0 & 18.1 & 0.09 & 0.375 \\
Milk production, kg/d & 21.8 & 21.0 & & 0.18 & 0.094 \\
Milk fat & 3.98 & 3.97 & 0.01 & 0.297 \\
\% & 861 & 824 & 12.6 & 0.170 \\
g/d & 3.13 & 3.10 & & 0.05 & 0.771 \\
Milk protein & 678 & 648 & 17.4 & 0.348 \\
g/d & 4.85 & 4.83 & & 0.04 & 0.699 \\
Lactose & 1057 & 1016 & 2.3 & 0.006 \\
g/d & & &
\end{tabular}

cultivars (dent/flint) and growing characteristics (Philippeau et al., 1999a). In the present study, dent and semiflint genotypes were tested, and characteristics (a, $\mathrm{b}$, and $\mathrm{c}$ parameters) of in situ starch degradation of ground grains were similar to those reported by Philippeau et al. (1999b) for dent and flint types. The difference in starch ERD observed between these 2 studies is mainly related to the particulate outflow rates used in ERD calculation. Nevertheless, the in situ technique revealed only a little variation (less than 5 points) in starch ERD between genotypes.

Longer rumen retention time has been observed for whole corn compared with for ground corn (Goetsch et al., 1987), and Ewing et al. (1986) showed that decreasing CPS resulted in a linear increase in the rate of passage from the rumen. In the present study, both genotypes particulate passage rate numerically increased between coarsely rolled and ground grain; however, the difference was not significant.

Lykos and Varga (1995) showed that in situ rumen starch digestion linearly decreases (from 0.65 to 0.45 ) with the mean particle size (from 0.69 to $4.31 \mathrm{~mm}$ ) of processed corn, suggesting that it could be possible to modulate rumen starch digestion by changes in the intensity of mechanical treatments. For both corn genotypes, in situ data obtained in the present study are consistent with those of Lykos and Varga (1995). A similar decrease in starch ERD was observed for dent and semiflint types between ground and coarsely rolled grains.

Few studies have attempted to evaluate in vivo the effect of mechanical processing of corn grain on starch digestion. A significant increase in rumen starch digestion between whole and processed grain was generally reported (Galyean et al., 1979; Turgeron et al., 1983; Bughardi et al., 1990). However, with high lysine cultivar of corn, Meissner et al. (1996) did not detect differences in starch digestion between whole and rolled grain. Galyean et al. (1979) and Knowlton et al. (1998) data suggested that once the corn kernel is broken by mechanical processing, mean particle size of processed corn has little impact on the extent of in vivo rumen starch digestion. However, in both studies, mean particle size after processing (grinding or rolling) remained relatively small (below $1.7 \mathrm{~mm}$ ). Yang et al. (2000) and Beauchemin et al. (2001) also reported that, for barley grain, mechanical processing did not affect rumen starch digestion. However, in their studies, grains were rolled and particle mean size remained large (above 3 $\mathrm{mm}$ ) whatever the treatment. In the present study, mean CPS ranged from 0.5 to $3.5 \mathrm{~mm}$, and for both corn genotypes in vivo starch digestion in the rumen increased between coarsely rolled and ground grains. This concurs with the observations of Callison et al. (2001) according to which nonstructural carbohydrate digestibility in the rumen increases between coarseground and fine-ground corn (mean particle size decreasing from 4.76 to $1.18 \mathrm{~mm}$ ). Although Callison et al. (2001) observed a quadratic effect of CPS, in the present study rumen starch digestibility of the semiflint genotype was linearly related to CPS. Again, this discrepancy could be explained by the difference in scale of particle size tested in both studies. Indeed, when corn grains are submitted to very coarse treatment, generating large particles or even leaving a lot of unaltered grains, ingestive mastication (Beauchemin et al., 1994) could lessen the effect of CPS and explain the quadratic effect observed by Callison et al. (2001). It is also noteworthy that, when comparing data of experiment 1 and 2 for ground corn, a difference of 10 points in starch ruminal digestibility was observed between dent and semiflint cultivars (twice that observed in sacco), and this difference increased with coarser particles.

Studies on digestion of starch from cereal grains in dairy cows fitted with duodenal and ileal cannulas are scarce (McNiven et al., 1995; Knowlton, 1998). Nevertheless, in cattle, when different types of processing 


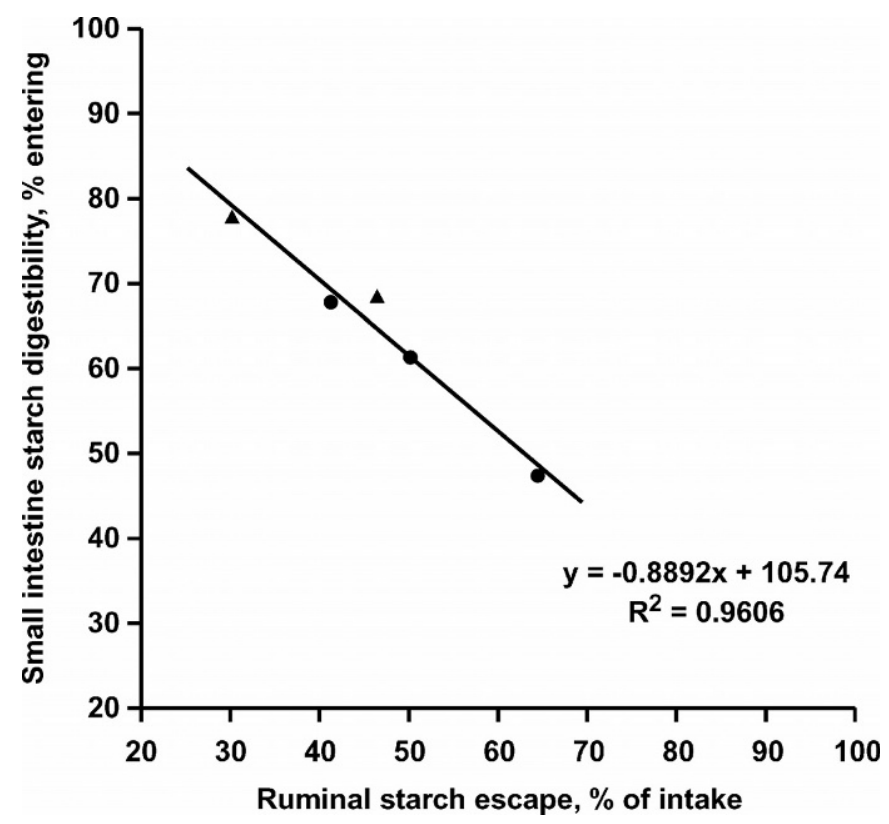

Figure 1. Relationship between the resistance of starch against rumimal degradation and starch digestibility in the small intestine $(\bullet$, experiment $1 ; \boldsymbol{\Delta}$, experiment 2$)$.

were applied to the same cereal, a decrease in rumen starch digestibility was generally associated with a decrease in small intestine digestibility (Zinn, 1990; Hill et al., 1991; McNiven et al., 1995; Knowlton et al., 1998). In agreement with this observation, in the present study where starch escape was modulated by mechanical processing, small intestine digestibility linearly decreased with rumen starch escape (Figure 1). This contrasts with the Callison et al. (2001) study, in which ruminal NSC digestibility decreased with CPS, small intestine digestibility of NSC was not affected. Basically, small intestine starch digestibility depends on enzymatic capacity for starch digestion, digesta transittime, and the accessibility of starch granules to enzymatic attack (Owens et al., 1986). In animals adapted to their diets, enzymatic capacity, per se, does not appear to limit the amount of starch digested in the small intestine (Mills et al., 1999b). Indeed, Van Vuuren et al. (1997) observed that up to $5 \mathrm{~kg}$ of starch could be digested in the small intestine of dairy cows, suggesting that in practical conditions small intestine starch digestibility is affected more by the physical characteristics of starch rather than by animal factors. In the present study, starch digestion in the small intestine did not exceed $1.5 \mathrm{~kg}$ and enzymatic capacity was probably not a limiting factor.

Although starch flow to the duodenum increases with particle size for both corn genotypes, the amount of starch digested in the small intestine tended to increase for dent corn but not for semiflint corn. The present work was not designed to compare corn genotypes. However care was taken to achieve both experiments in similar experimental conditions (same stage of lactation, same season, same diet), and it may be speculated that discrepancies between both experiments are mainly related to corn vitreousness, semiflint corn having greater vitreousness than dent corn. The vitreousness of the endosperm is related both to structural and chemical characteristics, and it was shown that protein distribution (zeins/glutelins) in the endosperm may significantly impact starch degradation in the rumen by affecting the accessibility of starch granules to microorganisms (Philippeau et al., 2000). In the present study, it was observed (visually) that the size of the corn particles that left the rumen increased from ground to coarsely rolled grain. Thus, for semiflint corn, the combination of particle size and vitreousness of the endosperm, which has limited rumen starch degradability, may have affected small intestine starch digestibility in similar fashion by limiting the accessibility of starch granules to digestive enzymes. However, other factors, such as physiological stage of corn grains at harvest, could also explain the differences in small intestinal digestion observed between both experiments.

For semiflint and dent genotype of corn, the decrease in rumen starch digestibility from ground to rolled grain was accompanied by a decrease in large intestine starch digestibility. Consequently, although ileal flow of starch was increased, the amount of starch digested in the large intestine was not modified and averaged $4 \%$ of starch intake. This concurs with the observations of Callison et al. (2001) according to which nonstructural carbohydrate digestibility in the large intestine is not affected by corn processing.

As previously reported, in lactating dairy cows receiving corn (Knowlton et al., 1998) or barley (Yang et al., 2000), total tract digestibility of starch decreased when the intensity of mechanical processing decreased. This effect was more significant for semiflint than for dent corn.

Whatever the corn genotype, although ruminal starch digestion increased by $1 \mathrm{~kg} / \mathrm{d}$ between ground and coarsely rolled grains, ruminal $\mathrm{pH}$ and VFA concentration were not affected. Similarly, in dairy cows Knowlton et al. (1996, 1998) and Callison et al. (2001) observed no variations in these ruminal traits according to mechanical processing of corn.

Microbial N flow to the duodenum was not significantly affected by corn processing. However, with both genotypes, it numerically decreased from ground to rolled grains. Consequently, although the amount of $\mathrm{OM}$ digested in the rumen decreased, the efficiency of microbial protein synthesis was not affected. Although 
the difference was not statistically significant, nonmicrobial N (i.e., feed + endogenous N) flowing to the duodenum increased from ground to rolled grains, probably as a consequence of the ruminal escape of corn proteins.

In the present work, shifting the site of starch digestion from the rumen to the small intestine (experiment 2 ) did not affect milk yield and composition. This observation is consistent with the fact that in dairy cows at similar levels of energy intake, as long as starch total tract digestibility is not affected, there is no direct benefit in a shift of the site of starch digestion. Indeed the nature of glucogenic substrates (propionate derived from starch fermentation or glucose derived from small intestine starch digestion) has little effect on milk yield and composition (Rigout et al., 2003).

\section{CONCLUSIONS}

This study showed that for semiflint corn it is best to finely ground the grains (mean particle size below 1 $\mathrm{mm}$ ), otherwise with increasing particle size the decrease in ruminal digestion is not compensated for by small intestine or large intestinal digestion and the total tract starch digestibility decreases. For dent genotype, with respect to grinding, rolling can allow part of starch digestion to be shifted from the rumen to the small intestine, with moderate effects on total tract starch digestibility (as long as processing does not leave too many unbroken grains). However, the effect of this displacement in the site of starch digestion, on the amount of starch digested in the small intestine, and therefore in glucose supply to the animal, remains quantitatively small. This study underlines the fact that, in lactating dairy cows, CPS is an important parameter in the estimation of starch digestibility in the various segments of the gut, and therefore in the prediction of the production and nature of energy substrates.

\section{REFERENCES}

Axe, D. E., K. K. Bolsen, D. L. Harmon, R. W. Lee, G. A. Milliken, and T. B. Avery. 1987. Effect of wheat and high-moisture sorghum grain fed singly and in combination on ruminal fermentation, solid and liquid flow, site and extent of digestion, and feeding performance of cattle. J. Anim. Sci. 64:897-906.

Beauchemin, K. A., T. A. McAllister, Y. Dong, B. I. Farr, and K.-J. Cheng. 1994. Effects of mastication on digestion of whole cereal grains by cattle. J. Anim. Sci. 72:236-246.

Beauchemin, K. A., W. Z. Yang, and L. M. Rode. 2001. Effects of barley grain processing on the site and extent of digestion of beef feedlot finishing diets. J. Anim. Sci. 79:1925-1936.

Burghardi, S. R., J. E. Garrett, R. D. Goodrich, and J. C. Meiske. 1990. Effects of dietary calcium, corn particle size, forage source, and cattle type on site and extent of digestion in steers. Can. J. Anim. Sci. 70:591-599.

Callison, S. L., J. L. Firkins, M. L. Eastridge, and B. L. Hull. 2001. Site of nutrient digestion by dairy cows fed corn of different particle sizes or steam-rolled. J. Dairy Sci. 84:1458-1467.
Elizalde, J. C., N. R. Merchen, and D. B. Faulkner. 1999. Supplemental cracked corn for steers fed fresh alfalfa: I. Effects on digestion of organic matter, fiber, and starch. J. Anim. Sci. 77:457-466.

Ewing, D. T., D. E. Johnson, and W. V. Rumpler. 1986. Corn particle passage and size reduction in the rumen of steers. J. Anim. Sci. 63:1509-1515.

Faichney, G. J. 1980. The use of markers to measure digesta flow from the stomach of sheep fed once daily. J. Agric. Sci. Camb. 94:313-318.

Faisant, N., V. Planchot, F. Kozlowski, M. P. Pacouret, P. Colonna, and M. Champ. 1995. Resistant starch determination adapted to products containing level of resistant starch. Sci. Aliment 15:83-89.

Garcia, S. C., F. J. Santini, and J. C. Elizalde. 2000. Sites of digestion and bacterial protein synthesis in dairy heifers fed fresh oats with or without corn and barley grain. J. Dairy Sci. 83:746-755.

Gaylean, M. L., D. G. Wagner, and F. N. Owens. 1979. Corn particle size and site and extent of digestion by steers. J. Anim. Sci. 49:204-210.

Goetsch, A. L., F. N. Owens, M. A. Funk, and B. E. Doran. 1987. Effects of whole or ground corn with different forms of hay in $85 \%$ concentrate diets on digestion and passage rate in beef heifers. Anim. Feed Sci. Technol. 18:151-164.

Harmon, D. L., and K. R. McLeod. 2001. Glucose uptake and regulation by intestinal tissues: Implications and whole-body energetics. J. Anim. Sci. 79(E. Suppl.):E59-E72.

Hibberd, C. A., D. G. Wagner, R. L. Hintz, and D. D. Griffin. 1985. Effect of sorghum grain variety and reconstitution on site and extent of starch and protein digestion in steers. J. Anim. Sci. 61:702-712.

Hill, T. M., S. P. Schmidt, R. W. Russel, E. E. Thomas, and D. F. Wolfe. 1991. Comparison of urea treatment with established methods of sorghum grain preservation and processing on site and extent of starch digestion by cattle. J. Anim. Sci. 69:4570-4576.

Jouany, J. P. 1982. Volatile fatty acids and alcohol determination in digestive contents, silage juices, bacterial cultures and anaerobic fermentor contents. Sci. Aliment 2:131-144.

Knowlton, K. F., M. S. Allen, and R. S. Erickson. 1996. Lasolacid and particle size of corn grain for dairy cows in early lactation. 2. Effect on ruminal measurements and feeding behavior. J. Dairy Sci. 79:565-574.

Knowlton, K. F., B. P. Glenn, and R. A. Erdman. 1998. Performance, ruminal fermentation, and site of starch digestion in early lactation cows fed corn grain harvested and processed differently. J. Dairy Sci. 81:1972-1984.

Lassalas, B., J. P. Jouany, and L. Broudiscou. 1993. Dosage des bases puriques et pyrimidiques par chromatographie liquide haute performance. Ann. Zootech. (Paris) 42(Suppl. 1):170.

Lykos, T., and G. A. Varga. 1995. Effects of processing method on degradation characteristics of protein and carbohydrate sources in situ. J. Dairy Sci. 78:1789-1801.

McNiven, J. A. N., M. R. Weisbjerg, and T. Hvelplund. 1995. Influence of roasting or sodium hydroxyde treatment of barley on digestion in lactating dairy cows. J. Dairy Sci. 78:1106-1115.

Meissner, H. H., D. V. Paulsmeier, K-J. Leeuw, and C. M. Coetzer. 1996. Ruminal and postruminal digestion of dietary protein and starch in steers: 2. Multivariate model prediction of non-ammonia nitrogen and starch passage and digestibility. S. Afr. Tydskr. Veek. 26(3/4):66-74.

Mills, J. A. N., J. France, and J. Dijkstra. 1999a. A review of starch digestion in the lactating dairy cow and proposals for a mechanistic model: Dietary starch characterization and ruminal starch digestion. J. Anim. Feed Sci. 8:291-340.

Mills, J. A. N., J. France, and J. Dijkstra. 1999b. A review of starch digestion in the lactating dairy cow and proposals for a mechanistic model: Postruminal starch digestion and small intestinal glucose absorption. J. Anim. Feed Sci. 8:451-481.

Oba, M., and M. S. Allen. 2003. Effects of corn grain conservation method on ruminal digestion kinetics for lactating dairy cows at two dietary starch concentrations. J. Dairy Sci. 86:184-194.

Ørskov, E. R., and I. McDonald. 1979. The estimation of protein degradability in the rumen from incubation measurements 
weighted according to rate of passage. J. Agric. Sci. (Camb.) 92:499-503.

Owens, F. N., D. S. Secrist, W. J. Hill, and D. R. Gill. 1998. Acidosis in cattle: A review. J. Anim. Sci. 76:275-286.

Owens, F. N., R. A. Zinn, and Y. K. Kim. 1986. Limits to starch digestion in the ruminant small intestine. J. Anim. Sci. 63:1634-1648.

Philippeau, C., F. Le Deschault de Monredon, and B. Michalet-Doreau. 1999a. Relationship between ruminal starch degradation and the physical characteristics of corn grain. J. Anim. Sci. 77:238-243.

Philippeau, C., C. Martin, and B. Michalet-Doreau. 1999b. Influence of grain source on ruminal characteristics and rate, site and extent of digestion in beef steers. J. Anim. Sci. 77:1587-1596.

Philippeau, C., J. Landry, and B. Michalet-Doreau. 2000. Influence of the protein distribution of maize endosperm on ruminal starch degradability. J. Sci. Food Agric. 80:404-408.

Rigout, S., C. Hurtaud, S. Lemosquet, A. Bach, and H. Rulquin. 2003. Lactational effect of propionic acid and duodenal glucose in dairy cows. J. Dairy Sci. 86:243-253.

Stock, R. A., D. R. Brink, R. A. Britton, F. K. Goedeken, M. H. Sindt, K. K. Kreimemeier, M. L. Bauer, and K. K. Smith. 1987. Feeding combinations of high moisture corn and dry-rolled grain sorghum to finishing steers. J. Anim. Sci. 65:290-302.

Streeter, M. N., R. G. Wagner, F. N. Owens, and C. A. Hibberd. 1989. Combination of high-moisture harvested sorghum grain and dry rolled corn: Effects on site and extent of digestion in beef heifers. J. Anim. Sci. 67:1623-1633.

Streeter, M. N., R. G. Wagner, C. A. Hibberd, and F. N. Owens. 1990 Comparison of corn with four sorghum grain hybrids: site and extent of digestion in steers. J. Anim. Sci. 68:3429-3440.

Streeter, M. N., R. G. Wagner, F. N. Owens, and C. A. Hibberd. 1991. The effect of pure and partial yellow endosperm sorghum grain hybrids on site and extent of digestion in beef steers. J. Anim. Sci. 69:2571-2584.

SAS User's Guide: Statistics, Version 6.03 edition. 1988. SAS Inst., Inc., Cary, NC.

Turgeon, O. A., D. R. Brink, and R. A. Britton. 1983. Corn particle size mixtures, roughage level and starch utilization in finishing steers diets. J. Anim. Sci. 57:739.

Van Vuuren, A. M., M. A. Gerritzen, and H. de Visser. 1997. Intestinal absorption of starch in dairy cows. J. Dairy Sci. 80(Suppl. 1):213. (Abstr.)

Waldo, D. R., L. W. Smith, E. L. Cox, B. T. Weinland, and H. L. Lucas. 1971. Logarithmic normal distribution for description of sieved forage materials. J. Dairy Sci. 54:1465-1469.

Wheatherburn, M. W. 1967. Phenol-hypochlorite reaction for determination of ammonia. Anal. Chem. 39:971-973.

Yang, W. Z., K. A. Beauchemin, and L. M. Rode. 2000. Effects of barley grain processing on extent of digestion and milk production of lactating cows. J. Dairy Sci. 83:554-568.

Zinn, R. A. 1990. Influence of steaming time on site of digestion of flaked corn in steers. J. Anim. Sci. 68:776-781. 